\title{
Effects of leavening agents in batter system on quality of deep-fried chicken breast meat
}

\author{
Rozzamri, A., Atiqah-Izyannie, A.M., Mat Yusoff, M. and *Ismail-Fitry, M.R. \\ Department of Food Technology, Faculty of Food Science and Technology, Universiti Putra Malaysia, \\ 43400 UPM Serdang, Selangor, Malaysia
}

\begin{abstract}
Article history:
Received: 4 August 2019

Received in revised form: 18 September 2019

Accepted: 20 September 2019

Available Online: 7 October 2019
\end{abstract}

\section{Keywords:}

Leavening agent,

Frying,

Yeast,

Baking powder,

Crispiness

DOI:

https://doi.org/10.26656/fr.2017.4(2).273

\begin{abstract}
The crispiness is an important parameter of battered chicken meat products and could be improved by adding leavening agents such as baking powder and dried yeast. This work was aimed to study the effect of different leavening agents added on the quality characteristics of battered chicken meat. Chicken breast meat strips were dipped into batters using different type of leavening agent; control (without a leavening agent); $4 \%$ baking powder (1), $4 \%$ dried yeast (2) and $2 \%$ baking powder $+2 \%$ dried yeast (3). The batter was kept in room temperature (RT) and cold temperature (CT) for one hour after coating. Moisture content, fat content, the viscosity of batter formulation, color, texture and sensory of fried battered chicken meat strips were evaluated. Moisture contents of RT3 and CT3 were significantly higher compared to other treatments while the fat content and viscosity of RT3 and CT3 were among the lowest. The RT2 and CT2 resulted in the lightest color. Compared to control samples, the addition of baking powder and yeast increased crispiness (fracturability and hardness) which was higher when used in combination than alone. Sensory evaluation of quality attributes showed crispiness and overall acceptability for RT3 and CT3 were among the highest. From the experiment, formulation 3 displayed the best effect of the leavening agents (a combination of baking powder and dried yeast) in batter system which produced lower fat, high moisture content, and crispier deep-fried chicken breast meat.
\end{abstract}

\section{Introduction}

White meat such as chicken breast without the skin is considered a healthier option as compared to red meat such as beef steak and pork chop due to its health advantages as it contains less fat (Pereira and Vicente, 2013). White meat is also easier to manage and has lesser religious boundaries (Liu et al., 2012). Due to these factors, the demand for chicken meat is growing. The commercial broiler business plays an important role to sustain the amount of production and delivery of chicken meat around the world (Jaturasitha et al., 2008). The popularity of chicken meat creates a niche market which provides more opportunities for food technologists to develop chicken meat into various processed foods such as chicken tenders, chicken frankfurters, and others. A variety of convenient and healthy chicken-based food products are high in demand and will attract consumers in this fast-paced era (Martínez Michel et al., 2011).

Fried food products generate a large sum of money every year worldwide. Fast-food chain depends critically on the frying procedure for cooking an assortment of foods including French fries, doughnut, burgers, frankfurters, and fish. The popularity of the frying procedure can be credited to the attributes of the fried foods. Frying contributes to the formation of crispy crust that can sustain the food from moisture loss (Innawong, 2001). Furthermore, deep-fat frying produces foods with a nice golden brown color, improves the product's physical appearance, and develops tempting aromas of the foods (Ishak et al., 2016) which are mainly important in enhancing the consumers' acceptance. The appearance of fried foods can be changed and further improved by varying the cooking methods, frying mediums, the composition of ingredients, additional of hydrocolloid in the batter, and selection of breading/coating (Kulp and Loewe, 1990; Meyers and Grazela, 2016).

It is critical that a specific level of binding is accomplished between batter and product uniformly. The batter should exhibit high crispiness upon frying while maintaining the naturally juicy and tender characteristics of the coated food. Cohesion-type of batter, also known as tempura, is a liquid batter consisting of leavening agent. The common types of leavening agents are sodium bicarbonate (Delcour et al., 1991), baking 
powder, yeast, and chemical leavenings, among others, which produce gas and contributes to the formation of small air bubbles (i.e. carbon dioxide) in the batter. Upon deep-fat frying, the small air bubbles grow in size and allow the batter to expand, thus further contribute to its desirable crispiness and assists in water lost as steam. Additionally, the batter foam dries out and exhibits a totally solid- and sponge-like structure (Baixauli et al., 2003). The use of leavening agent reduces the density and expand the volume of the coating so that it feels light on the tongue. In battered fried foods, the batter's crispiness is one of the major attributes affecting the consumers' acceptance (Vickers, 1998).

Characterization of deep-fat fried batters consisting of different leavening agents for food-coating purpose is under-studied. Therefore, the main goal of this research was to obtain a batter formulation which upon deep-fat frying, exhibiting desirable crispiness whilst minimizing the oil uptake into the coated fried food. The formulations varied in terms of the type and amount of leavening agents used, i.e. baking powder and yeast, while the coated food been tested was chicken breast meat strips. Furthermore, the effect of keeping temperature after coating the chicken strips with batter prior to deep-fat frying was also investigated.

\section{Materials and methods}

\subsection{Preparation of chicken breast meat}

The fresh chicken breast meat (Pectoralis major) was obtained from the local market (Pasar Borong Selangor) and was washed and cleaned. The chicken was dripped dry for 15 mins on top of a stainless steel wire mesh tray. The chicken meat was further hand-cut into 5 x 2 × $2 \mathrm{~cm}$ strips.

Table 1. Batter formulations for chicken breast meat

\begin{tabular}{ccccc}
\hline $\begin{array}{c}\text { Batter formulation } \\
(\% \text { w/w })\end{array}$ & $\begin{array}{c}\text { Wheat } \\
\text { flour }\end{array}$ & Salt & $\begin{array}{c}\text { Baking } \\
\text { powder }\end{array}$ & $\begin{array}{c}\text { Instant dried } \\
\text { yeast }\end{array}$ \\
\hline Control $(\mathrm{C})$ & 98 & 2 & - & - \\
1 & 94 & 2 & 4 & - \\
2 & 94 & 2 & - & 4 \\
3 & 94 & 2 & 2 & 2 \\
\hline
\end{tabular}

\subsection{Batter preparation}

The leavening agents (i.e. the baking powder and instant dry yeast), wheat flour, salt, and palm oil were purchased from the local market. The batter formulations were composed of 1.25:1 solid to water ratio in accord to a study done by Vongsawasdi et al. (2008), and all batter formulations prepared are shown in Table 1. The batter was prepared by mixing dry ingredients with water by using a mixer at the lowest speed for 3 mins. Each chicken strip was weighed before dipped into the batter to obtain the uniform weight of $12 \pm 2 \mathrm{~g}$. These batter- dipped chicken strips were placed in two different conditions; room temperature (RT) and cold temperature (CT) of below $4^{\circ} \mathrm{C}$ for $1 \mathrm{hr}$ prior to further frying process. Three batches were prepared for each batter formulation stored in each temperature.

\subsection{Viscosity of batter}

The viscosity of each batter formulation was measured at $25^{\circ} \mathrm{C}$ at $100 \mathrm{rpm}$ by using a viscometer (Rheolab QC Anton Paar, USA). The analysis was carried out in triplicate.

\subsection{Deep-fat frying process}

A total of $3 \mathrm{~L}$ of palm oil was preheated at $180 \pm 10^{\circ} \mathrm{C}$ for $15 \mathrm{mins}$ in a commercial bench-top deep fat fryer, and the coated chicken strips were further fried for 2 mins. The following methods (Methods 2.5-2.9) were carried out on the batter-coated fried chicken strips.

\subsection{Determination of moisture content}

The moisture content of the chicken samples was analyzed immediately after frying by using the oven drying method at $105 \pm 2^{\circ} \mathrm{C}$ according to AOAC (2005). Five grams of each chicken sample was dried until it reached a constant weight. The analysis was carried out in triplicate. The moisture content was calculated using the following formula:

\section{Moisture content $(\%)=(a-b) / a \times 100 \%$}

Where; $a$ is the initial weight of the sample and; $b$ is the weight of the dried sample.

\subsection{Determination of fat content}

Fat content was determined by using the dried chicken samples. Extraction of fat from these samples was carried out for $8 \mathrm{hrs}$ by using Soxhlet method with petroleum ether as the extracting solvent according to AOAC (2005). The analysis was carried out in triplicate. The fat content was calculated based on the following formula:

Fat content $(\%)=[($ weight of flask + oil $)-($ weight of flask)] / weight of sample x $100 \%$

\subsection{Color determination}

Color of the chicken samples was measured by using a chroma meter (CR - 300 Minolta, Japan). The color reading was expressed by CIE ( $\left.L^{*} a^{*} b^{*}\right)$ system. $L^{*}, a^{*}$, and $b^{*}$ indicated whiteness/darkness, redness/greenness, and blueness/yellowness, respectively. The analysis was carried out in triplicate. 


\subsection{Texture analysis}

A stable microsystem TA-XT2i Texture Analyser (UK) equipped with $25 \mathrm{~kg}$ of load cell was used to evaluate the texture of the chicken samples. An HDP/ BSK probe was used and a cutting knife blade set with $45^{\circ}$ chisel end was attached to the instrument. The pretest speed, test speed, and post-test speed were $1.00 \mathrm{~mm} /$ $\mathrm{sec}, 5.00 \mathrm{~mm} / \mathrm{sec}$, and $10.00 \mathrm{~mm} / \mathrm{sec}$, respectively, and 5 $\mathrm{g}$ of trigger force was used. The values of maximum peak force and the number of peaks were recorded.

\subsection{Sensory evaluation}

Sensory evaluation of the chicken samples was carried out by forty untrained panelists $(n=40)$. The panelists were instructed to rate the samples according to their level of acceptance in terms of color, appearance, taste, crispiness, juiciness, oiliness, and in overall by using 7-point hedonic scale, in accord to a study done by Gokalp et al. (1999).

\subsection{Statistical analysis}

Statistical software Minitab ${ }^{\circledR}$ Release 17, Copyright 2016 (Minitab Inc, Pennsylvania) was used for data analysis at $95 \%$ confidence level. A two-way Analysis of Variance (ANOVA) with Tukey's test was used to determine the significant difference between the samples. All data were presented as mean \pm standard deviation.

\section{Results and discussion}

Table 2 shows the viscosity of batter formulations consisting of different leavening agents (i.e. baking powder and instant dry yeast) prior to coating and frying the chicken strip samples. Table 2 also displays the physical and chemical properties of batter-coated chicken strip samples after deep-fat frying process.

\subsection{Viscosity}

Based on Table 2, RT3 and CT3 showed the lowest viscosity $(\mathrm{p}<0.05)$ when compared to the control sample. This is an indication that formulation 3 produces a low viscous batter. The viscosity can be related to the development of protein gluten which helps the batter rise by trapping air bubbles during mixing in both room temperature and cold temperature. Addition of leavening agents could expand the air bubbles, which strengthen the gluten thus produced thinner and less viscous batter. While the batter's viscosity is expected to increase with temperature reduction as observed in the control sample, the addition of leavening agents increased the viscosity of the batter's formulation when kept at room temperature compared to chilling temperature. This probably was due to the leavening agents that might be producing air bubbles slower at the chilling temperature that delayed the thickening of the batter.

In batter containing a leavening agent, a network of gluten protein structure retains the gas formed due to leavening effects. The higher the volume of gas being produced in the batter will result in a lower viscosity. Table 2 shows a significant difference $(p<0.05)$ between each formulation at both conditions. The amount of gas and its rate of production determine the viscosity of the batter. The air incorporated during the mixing of the batter with water also produces lower viscosity batter due to gravitational effect (Turabi et al., 2008). The viscosity of the batter plays an important role in determining a uniform thickness of the layer (Perera and Embuscado, 2014).

\subsection{Determination of moisture content}

Table 2 shows that at room temperature, RT3 recorded the highest moisture content $(46.90 \pm 0.33 \%)$ while RT1 showed the lowest moisture content $(36.90 \pm 0.36 \%)$. Table 2 dictates that each formulation does not show any significant difference when compared $(p>0.05)$ at different condition. However, a significant difference in moisture content was found when batter formulation was compared with each other $(\mathrm{p}<0.05)$.

Another observation made was that RT1 and CT1 displayed the lower value of moisture content when compared to control samples. Control sample which consists of only wheat flour has a strong gluten protein network. When gluten is combined with water and heated prior to the frying process, it forms an outer layer or crust on the surface of coating that acts as barriers for mass transfer during frying. This causes the moisture to be trapped inside the fried battered chicken samples. For formulation 1, the baking powder that was used as a leavening agent consists of a mixture of cornstarch, baking soda, and an acidic salt (tartaric acid). Corn starch is known to possess moisture absorbent properties. Formulation 1 recorded the lowest moisture content after deep frying most probably due to the water from the chicken meat and batter being absorbed by the corn starch. During frying, the heat causes the starch to bind with molecules of water inside the coating and from the chicken meat. This will cause moisture absorption by starch in the baking powder (Akdeniz et al., 2006). Control sample displayed slightly higher moisture content as compared to baking powder. According to Mehta and Swinburn (2001), the moisture loss will create vacuum spaces inside the food. During this stage, the oil will take over the vacuum spaces and is known as oil uptake during frying. Basically, the oil uptake is determined by the moisture content in the food. 
Table 2. The viscosity of batters consisting of different leavening agents (baking powder and instant dry yeast) prior to coating and frying, and physical and chemical properties of the batter-coated chicken strip samples after the deep-fat frying process

\begin{tabular}{|c|c|c|c|c|c|}
\hline \multirow{3}{*}{ Properties } & \multirow{3}{*}{$\begin{array}{c}\text { Keeping } \\
\text { condition }\left({ }^{\circ} \mathrm{C}\right)\end{array}$} & \multicolumn{4}{|c|}{ Batter formulation } \\
\hline & & Control & 1 & 2 & 3 \\
\hline & & $\begin{array}{c}\text { (0\% leavening } \\
\text { agent })\end{array}$ & $\begin{array}{c}\text { (4\% baking } \\
\text { powder, } 0 \% \text { yeast })\end{array}$ & $\begin{array}{c}(0 \% \text { baking } \\
\text { powder, } 4 \% \text { yeast })\end{array}$ & $\begin{array}{c}(2 \% \text { baking } \\
\text { powder, } 2 \% \text { yeast })\end{array}$ \\
\hline Viscosity & RT & $2023.40 \pm 7.77_{\mathrm{b}}^{\mathrm{A}}$ & $1821.90 \pm 7.35^{\mathrm{B}}$ & $1482.10 \pm 8.15^{\mathrm{C}}$ & $1271.50 \pm 8.17_{\mathrm{a}}^{\mathrm{D}}$ \\
\hline (Pa.S) & $\mathrm{CT}$ & $2229.90 \pm 7.42^{\mathrm{A}}$ & $1760.30 \pm 5.96^{\mathrm{B}}{ }_{\mathrm{b}}$ & $1481.80 \pm 8.76^{\mathrm{C}}{ }_{\mathrm{b}}$ & $1212.60 \pm 8.90^{\mathrm{D}}{ }_{\mathrm{b}}$ \\
\hline Moisture content & RT & $40.40 \pm 2.60_{\mathrm{b}}^{\mathrm{B}}$ & $36.90 \pm 0.36_{\mathrm{b}}^{\mathrm{C}}$ & $42.00 \pm 1.73^{\mathrm{B}}{ }_{\mathrm{a}}$ & $46.33 \pm 0.42^{\mathrm{A}}{ }_{\mathrm{b}}$ \\
\hline$(\% \mathrm{w} / \mathrm{w})$ & CT & $42.20 \pm 0.20^{\mathrm{C}} \mathrm{a}$ & $39.16 \pm 0.35^{\mathrm{D}}$ & $43.40 \pm 0.36^{\mathrm{B}}{ }_{\mathrm{a}}$ & $51.60 \pm 0.20_{\mathrm{a}}^{\mathrm{A}}$ \\
\hline Fat content & RT & $17.54 \pm 0.08_{\mathrm{a}}^{\mathrm{C}}$ & $24.76 \pm 1.37_{\mathrm{a}}^{\mathrm{A}}$ & $22.54 \pm 0.41_{\mathrm{a}}^{\mathrm{AB}}$ & $20.64 \pm 1.30_{\mathrm{a}}^{\mathrm{B}}$ \\
\hline$(\% \mathrm{w} / \mathrm{w})$ & $\mathrm{CT}$ & $15.74 \pm 0.44_{a}^{\mathrm{D}}$ & $26.25 \pm 0.15^{\mathrm{A}}$ & $23.51 \pm 0.57_{\mathrm{a}}^{\mathrm{B}}$ & $19.74 \pm 0.78_{\mathrm{a}}^{\mathrm{C}}$ \\
\hline \multicolumn{6}{|l|}{ Color profile } \\
\hline \multirow{2}{*}{$\mathrm{L}^{*}$} & RT & $47.24 \pm 0.39^{\mathrm{B}}{ }_{\mathrm{b}}$ & $48.29 \pm 0.37_{\mathrm{a}}^{\mathrm{B}}$ & $55.43 \pm 2.62^{\mathrm{A}}{ }_{\mathrm{a}}$ & $51.24 \pm 0.39^{\mathrm{A}}$ \\
\hline & $\mathrm{CT}$ & $48.01 \pm 2.28_{\mathrm{a}}^{\mathrm{B}}$ & $50.19 \pm 2.39^{\mathrm{AB}}$ & $54.71 \pm 0.37_{\mathrm{a}}^{\mathrm{A}}$ & $51.31 \pm 2.58^{\mathrm{AB}}{ }_{\mathrm{b}}$ \\
\hline \multirow{2}{*}{$a^{*}$} & RT & $14.33 \pm 0.17_{\mathrm{a}}^{\mathrm{A}}$ & $13.02 \pm 0.15^{\mathrm{B}}$ & $11.22 \pm 0.15_{\mathrm{b}}^{\mathrm{C}}$ & $13.08 \pm 0.34_{\mathrm{a}}^{\mathrm{B}}$ \\
\hline & $\mathrm{CT}$ & $15.38 \pm 1.07_{\mathrm{a}}^{\mathrm{AB}}$ & $15.92 \pm 0.81_{\mathrm{a}}^{\mathrm{A}}$ & $12.69 \pm 0.31_{\mathrm{a}}^{\mathrm{B}}$ & $13.34 \pm 1.92_{\mathrm{a}}^{\mathrm{AB}}$ \\
\hline \multirow{2}{*}{$b^{*}$} & RT & $29.16 \pm 0.37_{b}^{B}$ & $28.33 \pm 0.29^{B}{ }_{b}$ & $35.47 \pm 0.98_{\mathrm{a}}^{\mathrm{A}}$ & $34.53 \pm 1.38_{\mathrm{a}}^{\mathrm{A}}$ \\
\hline & $\mathrm{CT}$ & $31.04 \pm 1.93_{\mathrm{a}}^{\mathrm{A}}$ & $31.69 \pm 1.81_{\mathrm{a}}^{\mathrm{A}}$ & $33.51 \pm 0.88^{\mathrm{A}}$ & $34.48 \pm 0.41_{\mathrm{a}}^{\mathrm{A}}$ \\
\hline \multicolumn{6}{|l|}{ Texture profile } \\
\hline \multirow{2}{*}{ Fracturability } & RT & $902.50 \pm 56.10_{a}^{\mathrm{D}}$ & $1067.90 \pm 71.80^{\mathrm{C}}{ }_{\mathrm{b}}$ & $1273.20 \pm 32.90^{\mathrm{B}}$ & $1399.60 \pm 36.50^{\mathrm{A}}$ \\
\hline & CT & $1006.60 \pm 32.90^{\mathrm{D}}$ & $1259.20 \pm 38.50^{\mathrm{C}}{ }_{\mathrm{a}}$ & $1395.80 \pm 68.20^{\mathrm{B}}$ & $1526.30 \pm 24.60_{a}^{A}$ \\
\hline \multirow{2}{*}{ Hardness } & $\mathrm{RT}$ & $1406.50 \pm 27.00^{\mathrm{B}}{ }_{\mathrm{a}}$ & $1067.90 \pm 37.40_{\mathrm{b}}^{\mathrm{C}}$ & $2411.50 \pm 78.00^{\mathrm{A}}{ }_{\mathrm{b}}$ & $2312.30 \pm 69.30^{\mathrm{A}}{ }_{\mathrm{b}}$ \\
\hline & CT & $1450.50 \pm 24.90^{\mathrm{C}}{ }_{\mathrm{a}}$ & $1770.00 \pm 23.50^{\mathrm{A}}{ }_{\mathrm{a}}$ & $2340.40 \pm 63.10^{\mathrm{B}}$ & $2428.50 \pm 58.50_{a}^{\mathrm{A}}$ \\
\hline \multirow{2}{*}{ Cohesiveness } & RT & $0.26 \pm 0.00^{\mathrm{D}}$ & $0.27 \pm 0.00^{\mathrm{C}}{ }_{\mathrm{b}}$ & $0.29 \pm 0.00_{\mathrm{a}}^{\mathrm{B}}$ & $0.31 \pm 0.00_{\mathrm{a}}^{\mathrm{A}}$ \\
\hline & $\mathrm{CT}$ & $0.27 \pm 0.00^{\mathrm{D}}{ }_{\mathrm{a}}$ & $0.28 \pm 0.00_{a}^{\mathrm{C}}$ & $0.29 \pm 0.00^{\mathrm{B}}{ }_{\mathrm{a}}$ & $0.31 \pm 0.00^{\mathrm{A}}{ }_{\mathrm{a}}$ \\
\hline \multirow{2}{*}{ Adhesiveness } & RT & $-30.42 \pm 0.45^{\mathrm{D}}{ }_{\mathrm{b}}$ & $-23.24 \pm 0.45^{\mathrm{C}}{ }_{\mathrm{b}}$ & $-17.74 \pm 0.25^{\mathrm{B}}{ }_{\mathrm{b}}$ & $-13.47 \pm 0.02^{\mathrm{A}}{ }_{\mathrm{b}}$ \\
\hline & CT & $-28.44 \pm 0.04^{\mathrm{D}}{ }_{\mathrm{a}}$ & $-19.60 \pm 0.03^{C}{ }_{a}$ & $-16.38 \pm 0.01^{\mathrm{B}}{ }_{\mathrm{a}}$ & $-8.42 \pm 0.03_{\mathrm{a}}^{\mathrm{A}}$ \\
\hline \multirow{2}{*}{ Springiness } & RT & $0.85 \pm 0.01_{\mathrm{b}}^{\mathrm{C}}$ & $0.89 \pm 0.00_{\mathrm{b}}^{\mathrm{B}}$ & $0.90 \pm 0.00_{\mathrm{b}}^{\mathrm{B}}$ & $0.92 \pm 0.00_{\mathrm{b}}^{\mathrm{A}}$ \\
\hline & $\mathrm{CT}$ & $0.86 \pm 0.00_{\mathrm{a}}^{\mathrm{D}}$ & $0.90 \pm 0.00^{\mathrm{C}}{ }_{\mathrm{a}}$ & $0.91 \pm 0.02^{\mathrm{B}}{ }_{\mathrm{a}}$ & $0.93 \pm 0.00_{\mathrm{a}}^{\mathrm{A}}$ \\
\hline \multirow{2}{*}{ Chewiness } & RT & $311.18 \pm 4.50^{\mathrm{C}}{ }_{\mathrm{b}}$ & $395.40 \pm 12.92^{\mathrm{B}}{ }_{\mathrm{b}}$ & $633.39 \pm 24.21_{\mathrm{a}}^{\mathrm{A}}$ & $659.82 \pm 16.12^{\mathrm{A}}$ \\
\hline & CT & $341.20 \pm 9.25^{\mathrm{D}}{ }_{\mathrm{a}}$ & $450.37 \pm 2.54_{\mathrm{a}}^{\mathrm{C}}$ & $638.19 \pm 18.51_{\mathrm{a}}^{\mathrm{B}}$ & $688.37 \pm 17.40^{\mathrm{A}}$ \\
\hline
\end{tabular}

Capital letters superscript row-wise are significantly different $(p<0.05)$ between formulations.

Small letters superscript column-wise are significantly different $(p<0.05)$ between conditions (temperature) within the respective analysis.

RT and CT represent the keeping temperatures of batters and batter-coated chicken strip samples prior to deep-fat frying. RT, room temperature; $\mathrm{CT}$, chilling temperature $\left(4^{\circ} \mathrm{C}\right)$

Sustaining high moisture content in battered chicken samples resulted in low oil uptake after the frying process.

\subsection{Determination of fat content}

The fat content at room and cold temperatures in battered fried chicken samples varied from $17 \%$ to $24 \%$ and $15 \%$ to $26 \%$, respectively. RT1 and CT1 recorded the highest fat content. This result is in agreement with the previous result where moisture content affects the amount of oil uptake (fat). As stated before, formulation 1 displayed a significant difference $(\mathrm{p}<0.05)$ in moisture content for both conditions. During frying, the amount of oil uptake has been appeared to be specifically corresponding to the amount of moisture loss. The oil uptake in the batter coating occurs as moisture has been removed from the batter system during the frying process (Ateba and Mittal, 1994).

During the deep-fat frying process, several chemical and physical factors will affect the oil uptake. Several reactions such as water vaporization, crust formation, protein denaturation, and starch gelatinization cause a change in the amount of oil uptake (Pinthus et al., 1995). Sustaining high moisture content in the samples will result in low-fat content. The temperature of oil also plays an important role in oil uptake during frying. Another factor that can affect the oil uptake in the samples is the frying time and oil temperature. The optimum oil temperature to minimize oil uptake during frying was reported between the range of $175^{\circ} \mathrm{C}$ to $190^{\circ} \mathrm{C}$ (Innawong, 2001). In this experiment, all four 
formulations of battered chicken samples were fried at $180^{\circ} \mathrm{C}$ for 2 mins.

As shown in Table 2, all samples that have a leavening agent in it (baking powder and yeast) has a significantly higher percentage of fat $(\mathrm{p}<0.05)$ compared to control formulation. The leavening agent helps to increase the surface area of coating samples with the aids of bubbles or gas produce by carbon dioxide when mixing with water (Delcour et al., 1991). The production of carbon dioxide by baking powder and yeast permeates the batter and intermingles with it. When heat is applied as in frying, the gas expands and produces porous mass. As the heat continues, the framework becomes more solid and open sponge-like which forms a crispy outer layer (Fiszman and Salvador, 2003). As the moisture in the batter converts into steam, it creates a sponge-like tunnel network constitutes to replace oil during frying. According to Moreno and Bouchon (2008), the outer layer formation of battered coating has been one of vital reason for final oil uptake into the product. The direct influence of oil uptake in the samples has been pore development and pore size distribution (Pinthus et al., 1995). In addition, the data shows that RT1 and CT1 possess the highest percentage of oil uptake. The commercialized baking powder used in this experiment is also known as the double-acting baking powder. It means it dissolves rapidly in liquid, begins acting right away and expands twice the normal when the heat is being used. By using baking powder, time consumption is reduced when compared to using yeast. This is because yeasts need a sufficient amount of time to let the microorganism grow and the duration is for at least 1 hour (Salazar et al., 2004). Formulation of batter using yeast will suggest a lower oil uptake when compared to using $4 \%$ baking powder. This might be due to the porous network built by carbon dioxide gas released by yeast is lower than in baking powder. No significant difference $(p>0.05)$ was found when all samples were compared between the two conditions. The temperature of oil used during frying might be the core factor of oil uptake rather than the batter temperature.

\subsection{Color analysis}

Table 2 shows the color values $\left(\mathrm{L}^{*}, \mathrm{a}^{*}\right.$ and $\left.\mathrm{b}^{*}\right)$ of batter-coated fried chicken strips. A total of 24 fried chicken strips, in triplicates, were used to determine the color. From the result, RT3 and CT3 were considered as the lightest as indicated by the higher $L^{*}$ values $(p<0.05)$, less yellow as indicated by higher $b^{*}$ values $(p<0.05)$ and had no uniform $a^{*}$ values $(p<0.05)$ when compared to control.

Lightness represents the reflection of light which is highly affected by fat content and extracellular water of the chicken meat product. This is reported by Barbut and Mittal (1990) which stated that a lighter color of meat product is affected by the higher content of fat (with a higher proportion of white fat). However, increased extracellular water can also increase the refraction of light, leading to a higher $\mathrm{L}^{*}$ value. Whereas, an increase in bound water (intracellular), can absorb light resulting in a darker color with lower $\mathrm{L}^{*}$ value (Barbut and Mittal, 1990). In the room temperature, lightness value ( $\left.\mathrm{L}^{*}\right)$ was significantly higher $(\mathrm{p}<0.05)$ in RT2 followed by RT1, RT3, and control. At cold temperature condition, the result of lightness value displayed a similar result with room condition. The $\mathrm{L}^{*}$ value was significantly higher $(p<0.05)$ in CT3 followed by CT2, CT1, and control. Redness ( $\left.a^{*}\right)$ for all samples in room temperature was significantly different $(\mathrm{p}<0.05)$ and control displayed the highest value of redness. At cold temperature, redness value was slightly higher in CT2 (15.92) compared with control formulation which was 15.38 .

For yellowness $\left(b^{*}\right)$, RT2 and RT3 displayed no significant difference $(\mathrm{p}>0.05)$ when compared to RT1. However, a significant difference $(\mathrm{p}<0.05)$ was found when compared to control. In contrast, at cold temperature, $b^{*}$ values showed no significant differences $(p>0.05)$ between all samples. Generally, the frying process significantly $(p<0.05)$ increases the lightness $\left(\mathrm{L}^{*}\right)$ and decreases redness $\left(\mathrm{a}^{*}\right)$ and yellowness $\left(\mathrm{b}^{*}\right)$ values of the battered chicken samples. This might occur due to protein denaturation process in wheat flour and transformation of myoglobin into metmyoglobin during the frying process. The changes in color observed in this experiment could be attributed to appearance during sensory evaluation.

\subsection{Texture analysis}

The texture of batter-coated fried chicken strips products possesses many characteristics, however, hardness and fracturability, which describe the textural attributes of the substrate, and crunchiness, which can be translated as the crust is considered as the most important attribute (Luyten et al., 2004). Other textural attributes which were analyzed using Texture Profile Analyzer were cohesiveness, adhesiveness, springiness, and chewiness. The textural performance of the product was compared with the fracturability data analysis, which will be a good indicator of crispiness. Table 2 depicts that control formulation does not show a statistically significant difference $(p>0.05)$ between both batter condition.

Higher mean values indicate higher crispiness of the fried battered chicken samples. From the data obtained, CT3 gives the highest mean on fracturability which was $1526.3 \mathrm{~g}$ followed by RT3 which was $1399.6 \mathrm{~g}$. 
According to Salvador et al. (2002), leavening agent greatly influences the final texture of the coating/crust layer of the fried food product. It contributes to the crispiness required by fried food. Furthermore, the amylose content of the starches enhanced the polysaccharide-polysaccharide interaction which provides the crispiness to the fried chicken. In this research, the leavening agent gives the highest effect to the crust crispiness due to the production of carbon dioxide gas in both baking powder and yeast respectively.

\subsection{Sensory evaluation}

Sensory evaluation data is shown in Table 3. A significant different $(p<0.05)$ was reported on the color attribute of each formulation. At cold temperature condition, CT3 gives the highest significant score $(p<0.05)$ which was $6.10 \pm 0.84$ when compared to other formulation. This suggests that the majority of panelist preferred the color of deep fry battered chicken that is affected by a combination of $2 \%$ baking powder and $2 \%$ yeast. Same goes to appearance attribute, panelist preferred CT3. Color is one of the most important physical attributes that greatly influence consumer perception and can summarily lead to rejection of a product. Thus, making color and appearance correlate and depends on each other. Consumers tend to choose food product with great appearance and color.

For the taste quality attribute, all batter formulation showed no significant different $(p>0.05)$ whereas crispiness attribute recorded a significant difference $(p<0.05)$ between batter formulations for both conditions. Crispy texture is one of the vital properties of fried food products and affects the acceptability of fried food products. Generally, the color was rated high by participants obtaining a mean score of 5.8 for CT3. Subsequently, control formulation for both conditions displayed the lowest score (4.20) and panelists were indifferent (neither like nor dislike) about the crispiness. These two samples observed showed no significant different $(p>0.05)$ between each other. The crispiness of the sample might be affected by air spaces formed within the crisp structure, moisture uptake after frying and sogginess (Mellema, 2003).

For the juiciness quality attribute, this attribute might be related to moisture trapped inside the coating. Overall, the juiciness of the fried battered chicken samples displayed a significant different $(p<0.05)$ in each formulation. The highest mean score was RT3 with a mean score of 5.63. The combination of baking powder and yeast produces the best carbon dioxide output which allowed the formation of crust directly during frying and act as mass transfer barrier in term of oil absorption into the samples and prevented moisture loss (Pinthus et al., 1995). This score showed that panelist preference, 'slightly like' towards the fried battered chicken in RT3. The juiciness attributes also presented a similar result as crispiness where the two samples from control formulation indicated no significant different $(\mathrm{p}<0.05)$. For the oiliness attribute, a significant difference can be observed when all the samples were compared $(p<0.05)$. The highest significant $(\mathrm{p}<0.05)$ score is marked as acceptable for samples to be eaten because of the low oil content present within the fried battered chicken.

Table 3. Sensory acceptance of chicken strips coated with batters consisting of different leavening agents (baking powder and instant dry yeast)

\begin{tabular}{|c|c|c|c|c|c|}
\hline \multirow{3}{*}{$\begin{array}{c}\text { Sensory } \\
\text { properties }\end{array}$} & \multirow{3}{*}{$\begin{array}{l}\text { Keeping } \\
\text { condition } \\
\left({ }^{\circ} \mathrm{C}\right)\end{array}$} & \multicolumn{4}{|c|}{ Batter formulation } \\
\hline & & Control & 1 & 2 & 3 \\
\hline & & $\begin{array}{c}\text { (0\% leavening } \\
\text { agent) }\end{array}$ & (4\% baking & ( $0 \%$ baking & ( $2 \%$ baking \\
\hline \multirow{2}{*}{ Color } & RT & $5.70 \pm 0.97^{\mathrm{AB}}$ & $5.83 \pm 1.08^{\mathrm{AB}}$ & $5.98 \pm 0.77^{\mathrm{A}}$ & $5.85 \pm 1.21^{\mathrm{A}}$ \\
\hline & $\mathrm{CT}$ & $5.10 \pm 1.57^{\mathrm{B}}$ & $5.90 \pm 1.17^{\mathrm{A}}$ & $5.88 \pm 1.31^{\mathrm{A}}$ & $6.10 \pm 0.84^{\mathrm{A}}$ \\
\hline \multirow{2}{*}{ Appearance } & RT & $5.48 \pm 1.19^{\mathrm{AB}}$ & $5.60 \pm 1.32^{\mathrm{AB}}$ & $5.58 \pm 1.36^{\mathrm{AB}}$ & $5.50 \pm 1.30^{\mathrm{AB}}$ \\
\hline & CT & $4.90 \pm 1.69^{\mathrm{B}}$ & $5.88 \pm 1.22^{\mathrm{A}}$ & $5.73 \pm 1.39^{\mathrm{AB}}$ & $5.88 \pm 0.85^{\mathrm{A}}$ \\
\hline \multirow{2}{*}{ Taste } & RT & $5.33 \pm 1.60^{\mathrm{A}}$ & $5.33 \pm 1.33^{\mathrm{A}}$ & $5.65 \pm 0.66^{\mathrm{A}}$ & $5.33 \pm 1.25^{\mathrm{A}}$ \\
\hline & $\mathrm{CT}$ & $5.10 \pm 1.53^{\mathrm{A}}$ & $5.50 \pm 0.88^{\mathrm{A}}$ & $5.48 \pm 1.22^{\mathrm{A}}$ & $5.50 \pm 1.19^{\mathrm{A}}$ \\
\hline \multirow{2}{*}{ Crispiness } & RT & $4.20 \pm 1.79^{\mathrm{C}}$ & $4.63 \pm 1.37^{\mathrm{BC}}$ & $5.13 \pm 1.45^{\mathrm{B}}$ & $5.80 \pm 1.11^{\mathrm{A}}$ \\
\hline & $\mathrm{CT}$ & $4.28 \pm 1.85^{\mathrm{C}}$ & $4.98 \pm 1.25^{\mathrm{BC}}$ & $5.48 \pm 1.22^{\mathrm{AB}}$ & $5.55 \pm 1.36^{\mathrm{AB}}$ \\
\hline \multirow{2}{*}{ Juiciness } & RT & $4.00 \pm 1.68^{\mathrm{C}}$ & $4.48 \pm 1.88^{\mathrm{BC}}$ & $5.15 \pm 1.67^{\mathrm{AB}}$ & $5.63 \pm 1.17^{\mathrm{A}}$ \\
\hline & $\mathrm{CT}$ & $4.10 \pm 1.61^{\mathrm{C}}$ & $4.63 \pm 1.44^{\mathrm{B}}$ & $5.30 \pm 1.23^{\mathrm{AB}}$ & $5.20 \pm 1.47^{\mathrm{AB}}$ \\
\hline \multirow{2}{*}{ Oiliness } & RT & $4.25 \pm 1.52^{\mathrm{AB}}$ & $3.63 \pm 1.78^{\mathrm{AB}}$ & $4.50 \pm 1.75^{\mathrm{A}}$ & $3.83 \pm 1.57^{\mathrm{AB}}$ \\
\hline & $\mathrm{CT}$ & $3.43 \pm 1.34^{\mathrm{B}}$ & $3.98 \pm 1.56^{\mathrm{AB}}$ & $3.35 \pm 1.37^{\mathrm{B}}$ & $4.18 \pm 1.66^{\mathrm{AB}}$ \\
\hline Overall & RT & $4.63 \pm 1.29^{\mathrm{AB}}$ & $5.03 \pm 1.29^{\mathrm{AB}}$ & $5.25 \pm 1.46^{\mathrm{A}}$ & $5.33 \pm 1.37^{\mathrm{A}}$ \\
\hline Acceptability & CT & $4.28 \pm 1.39^{\mathrm{B}}$ & $4.90 \pm 1.28^{\mathrm{AB}}$ & $5.25 \pm 1.01^{\mathrm{A}}$ & $5.18 \pm 1.15^{\mathrm{A}}$ \\
\hline
\end{tabular}

Different letters in the same row indicate significant difference for each attribute $(p<0.05)$.

RT and CT represent the keeping temperatures of batter-coated chicken strip samples prior to deep-fat frying. RT, room temperature; $\mathrm{CT}$, chilling temperature $\left(4^{\circ} \mathrm{C}\right)$ 
Formulation 2 which contain yeast recorded a score of 4.5 and was categorized by the panelist as the lowest oil content. Control batter formulation at cold temperature recorded the lowest mean score of 4.28 for overall acceptability. It was considerably different from room temperature and cold temperature of formulation 1,2 and 3 for overall acceptability. Based on the mean score for overall acceptability, RT3 score more than 5.0 which was 'slightly like' on the 7-point Hedonic Scale and indicated the most preferable sample for the forty panelists.

\section{Conclusion}

Combination of dried yeast and baking powder (Formulation 3) has been found to be the most effective leavening agent on the batter performance. It provided the highest moisture content and lowest oil uptake after control formulation in both RT and CT condition. Chicken breast meat dipped into yeast and baking powder formulation resulted in higher fracturability and hardness values compared to the control formulation. The value of lightness (L) was among the lowest when compared to the other two formulations, while, the panelists also preferred formulation 3 to other treatments. As a conclusion, the results proved that leavening agents have a positive effect on the quality characteristics of battered chicken products in terms of producing healthier product (low-fat uptake) and a better texture (high in moisture and crispiness).

\section{References}

Akdeniz, N., Sahin, S. and Sumnu, G. (2006). Functionality of batters containing different gums for deep-fat frying of carrot slices. Journal of Food Engineering, 75(4), 522-526. https:// doi.org/10.1016/j.jfoodeng.2005.04.035

Ateba, P. and Mittal, G.S. (1994). Modelling the deep-fat frying of beef meatballs. International Journal of Food Science and Technology, 29(4), 429-440. https://doi.org/10.1111/j.1365-2621.1994.tb02084.x

Baixauli, R., Sanz, T., Salvador, A. and Fiszman, S.M. (2003). Effect of the addition of dextrin or dried egg on the rheological and textural properties of batters for fried foods. Food Hydrocolloids, 17(3), 305-310. https://doi.org/10.1016/S0268-005X(02)00091-7

Barbut, S. and Mittal, G.S. (1990). Effect of heating rate on meat batter stability, texture and gelation. Journal of Food Science, 55(2), 334-337. https:// doi.org/10.1111/j.1365-2621.1990.tb06756.x

Chen, S.L. and Gutmanis, F. (1976). Carbon dioxide inhibition of yeast growth in biomass production. Biotechnology and Bioengineering, 18(10), 1455-
1462. https://doi.org/10.1002/bit.260181012

Cunningham, F.E. and Tiede, L.M. (1981). Influence of batter viscosity on breading of chicken drumsticks. Journal of Food Science, 46(6), 1950-1950. https:// doi.org/10.1111/j.1365-2621.1981.tb04527.x

Delcour, Jan. Degeest, C., Hoseney, R.C. and Shelke, K. (1991) Glycine derivatives as the source of carbondioxide in cake formulations. Cereal Chemistry, 68 (4), 369-371

De Liu, X., Jayasena, D.D., Jung, Y., Jung, S., Kang, B.S., Heo, K.N., Lee, J.H. and Jo, C. (2012). Differential proteome analysis of breast and thigh muscles between Korean native chickens and commercial broilers. Asian-Australasian Journal of Animal Sciences, 25(6), 895. https://doi.org/10.5713/ ajas.2011.11374

Fiszman, S. M. and Salvador, A. (2003). Recent developments in coating batters. Trends in Food Science and Technology, 14(10), 399-407. https:// doi.org/10.1016/S0924-2244(03)00153-5

Gokalp, H.Y., Kaya, M., Tulek, Y. and Zorba, O. (1999). Practical laboratory guide and quality control in meat and meat products. Turkey: Atatürk University.

Innawong, B. (2001). Improving fried product and frying oil quality using nitrogen gas in a pressure frying system. Virginia, USA: Virgina Tech, PhD Dissertation.

Ishak, A.J., Rahman, R.A., Soh, A.C., Shamsudin, R., Jalo, S.A., Lim, F.C. and Lin, H.K. (2016). Quality identification of used cooking oil based on feature fusion of gas sensor and color. International Science Press, 9(5), 321-329

Jaturasitha, S., Srikanchai, T., Kreuzer, M. and Wicke, M. (2008). Differences in carcass and meat characteristics between chicken indigenous to northern Thailand (Black-boned and Thai native) and imported extensive breeds (Bresse and Rhode Island Red). Poultry Science, 87(1), 160-169. https:// doi.org/10.3382/ps.2006-00398

Luyten, H., Plijter, J.J. and Van Vliet, T. (2004). Crispy/ crunchy crusts of cellular solid foods: a literature review with discussion. Journal of Texture Studies, 35(5), 445-492. https://doi.org/10.1111/j.17454603.2004.35501.x

Kulp, K. and Loewe, R. (1990). Batters and breading in Food Processing., p. 14-16. America: Academic Press.

Martínez Michel, L., Anders, S. and Wismer, W.V. (2011). Consumer Preferences and willingness to pay for value-added chicken product attributes. Journal of Food Science, 76(8), S469-S477. https:// doi.org/10.1111/j.1750-3841.2011.02354.x 
Mehta, U. and Swinburn, B. (2001). A review of factors affecting fat absorption in hot chips. Critical Reviews in Food Science and Nutrition, 41(2), 133154. https://doi.org/10.1080/20014091091788

Mellema, M. (2003). Mechanism and reduction of fat uptake in deep-fat fried foods. Trends in Food Science and Technology, 14(9), 364-373. https:// doi.org/10.1016/S0924-2244(03)00050-5

Meyers, M.A. and Grazela, A. (2016). Functionality of hydrocolloids in batter coating systems. In Kulp, K., Loewe, R., Lorenz, K. and Gelroth, J. (Eds). Batters and breadings in food processing. $2^{\text {nd }}$ ed., p. 117138. Minnesota: AACC International Inc. https:// doi.org/10.1016/B978-1-891127-71-7.50012-7

Moreno, M.C. and Bouchon, P. (2008). A different perspective to study the effect of freeze, air, and osmotic drying on oil absorption during potato frying. Journal of Food Science, 73(3), 122-128. https://doi.org/10.1111/j.1750-3841.2008.00669.x

Pereira, P.M.D.C.C. and Vicente, A.F.D.R.B. (2013). Meat nutritional composition and nutritive role in the human diet. Meat Science, 93(3), 586-592. https:// doi.org/10.1016/j.meatsci.2012.09.018

Perera, C. and Embuscado, M.E. (2014). Texture design for breaded and battered foods. In Dar, Y.L. and Light, J. M. (Eds.). Food texture design and optimization, p. 128-158. Chicago, IL: John Wiley and Sons, Ltd and the Institute of Food Technologists. doi.org/10.1002/9781118765616.ch7

Pinthus, E.J., Weinberg, P. and Saguy, I.S. (1995). Oil uptake in deep fat frying as affected by porosity. Journal of Food Science, 60(4), 767-769. https:// doi.org/10.1111/j.1365-2621.1995.tb06224.x

Salazar, J., Turó, A., Chávez, J.A. and García, M.J. (2004). Ultrasonic inspection of batters for on-line process monitoring. Ultrasonics, 42(1-9), 155-159. https://doi.org/10.1016/j.ultras.2004.02.017

Salvador, A., Sanz, T. and Fiszman, S. (2002). Effect of corn flour, salt, and leavening on the texture of fried, battered squid rings. Journal of Food Science, 67(2), 730-733. https://doi.org/10.1111/j.13652621.2002.tb10667.x

Turabi, E., Sumnu, G. and Sahin, S. (2008). Rheological properties and quality of rice cakes formulated with different gums and an emulsifier blend. Food Hydrocolloids, 22(2), 305-312. https:// doi.org/10.1016/j.foodhyd.2006.11.016

Vickers, Z.M. (1988). Instrumental measures of crispness and their correlation with sensory assessment. Journal of Texture Studies, 19(1), 1-14. https://doi.org/10.1111/j.1745-4603.1988.tb00920.x
Vongsawasdi, P., Wongwichan, A., Khunajakr, N. and Dejsuk, N. (2008). Shelf-life extension of fried battered chicken by modified atmosphere packaging. Asian Journal of Food and Agro-Industry, 1(4), 197204. 